\title{
HOMOSSEXUALIDADE E IDENTIDADE TRANS NO ISLÃ ${ }^{12}$
}

\author{
Ludovic Mohamed Zahed ${ }^{3}$
}

\begin{abstract}
Resumo: Muitas vezes me deparo com indivíduos que estão pessoalmente preocupados ou não com a questão, que ouviram tanto sobre o assunto, e seus opostos, que querem ter uma ideia ao mesmo tempo sintética e global desta questão, do ponto de vista da chamada tradição árabe-muçulmana. Eu proponho resumir aqui as fontes das escrituras islâmicas relacionadas à questão da diversidade de naturezas, gêneros, sexualidades humanas. Assim, em uma abordagem certamente mais comprometida politicamente do que a da maioria dos intelectuais de nosso tempo, posso, ao mesmo tempo, esclarecer certas noções teológicas que podem parecer herméticas para os não iniciados.
\end{abstract}

Palavras-Chave: Homossexualidade; Identidade trans; Islã.

\section{HOMOSEXUALITY AND TRANS IDENTITY IN ISLAM}

\begin{abstract}
Often I come across individuals who are personally concerned or not with the question, who have heard so much about it, and their opposites, who want to have an at once synthetic and global idea of this issue, from the point of view of the so called tradition Arab-Muslim world. I propose to summarize here the sources of the Islamic writings related to the question of the diversity of natures, genders, human sexualities. Thus, in an approach certainly more politically committed than that of most intellectuals of our time, I can at the same time clarify certain theological notions that may seem hermetic to the uninitiated.
\end{abstract}

Keywords: Homosexuality; Trans identity; Islam.

\section{Introdução}

Ouça esta famosa história que relata como um homem foi submetido à punição do flagelo. Durante as primeiras noventa e nove chicotadas, não deixou escapar um gemido de dor sequer, mas quando ele recebeu a última das cem chicotadas, ele suspirou em uma longa agonia. As pessoas que estavam ao seu redor perguntaram sobre essa atitude estranha e o homem respondeu: Durante as primeiras noventa e nove chicotadas, meu parceiro e a razão do amor pelo qual fui chicoteado, estavam perto de mim, entre o círculo de espectadores que testemunharam meu castigo doloroso. Foi só quando ele se afastou de mim que, de repente, senti a dor ${ }^{4}$.

$\mathrm{Eu}$ sempre me encontro diante de indivíduos que estão mais ou menos interessados e perguntam, porque já ouviram falar muito sobre o assunto e querem ter uma idéia sintética e global, do ponto de vista da chamada tradição árabe-muçulmana.

\footnotetext{
${ }^{1}$ Tradução para o Português (BR): Regina Márcia Oliveira de Faria.

${ }^{2}$ NOTA DA TRADUTORA: A tradução para o idioma Português (BR) buscou preservar as explanações do autor, contextualizadas para a gramática e leitura de estudiosos religiosos e leigos que e como se fala o português do Brasil. No conteúdo foi preservado também o tradutor do idioma Espanhol propositalmente, por se tratar de generosidade de Imam Ludovic-Mohamed Zahed para que fosse possível mais e melhor aprender e apreender para a estudante muçulmana Regina Márcia, brasileira e residente no Brasil. Nossa mais sincera e profunda gratidão.

${ }^{3}$ Rector of the CALEM Institute - Research, counseling, trainigns \& editions in Islamic and social sciences: secularism, inter-culturalism, gender \&religiosity

${ }^{4}$ Ibn 'Ata Allah Al-Iskandar, traducción de Kugle, S. (2005). "The book of illumination" [Kitab AlTanwir], p. 65. Ibn 'Ata Allah Al-Iskandar, tradução de Kugle, S. (2005). "O livro de iluminação" [Kitab Al-Tanwir], p. 65.
} 
Por isso, proponho-me aqui a recapitular as fontes islâmicas que lidam com a questão da diversidade de naturezas, gêneros e sexualidades humanas, com um enfoque mais comprometido com o ponto de vista político do que a maior parte dos intelectuais franceses, para que possa especificar, ao mesmo tempo, certas noções teológicas que possam parecer um pouco herméticas ${ }^{5}$ para aqueles que não estão familiarizados.

Apesar das lacunas e controvérsias que esses tipos de abordagens levantam hoje, o paradigma da teologia sistemática e sistêmica terá influenciado toda uma geração de cidadãs e cidadãos comprometidos com os direitos humanos. Além disso, os pesquisadores estão se tornando mais numerosos quando vêem nessa alternativa uma abordagem para o futuro, comprometida com uma causa e que traz um estudo sério, embora muitos considerem também "militantes", não com objetivo político, mas, nuançada de religiosidade. Se o fato de lidar com a questão religiosa não é tolerado, por que não deixamos o campo aberto a representações identitárias e políticas mais extremas em relação a esta questão?

\section{Ética do Alcorão de "natureza": gênero, sexualidade e diversidade}

No Alcorão, a diversidade é uma "realidade positiva", inserido no coração do Cosmos, de forma particularmente especial, para despertar em nós as perguntas necessárias para superar o egocentrismo, discriminação, exclusão e violência:

Oh humanos! Nós criamos você de um macho e uma fêmea, e vos dividimos em povos e tribos para reconhecerdes uns aos outros. Em verdade, sabeis que o mais nobre dentre vós, diante de Deus, é o mais temente $[\ldots]^{7}$.

Desta forma, a diversidade de gêneros humanos é apresentada como um sinal de poder do Criador. Isso também se aplica ao resto das expressões da criatura humana, diversas e variadas: "E entre seus presságios está a criação dos céus e da terra, e a diversidade de suas línguas e cores. Pois certamente, nisso existem de fato, mensagens

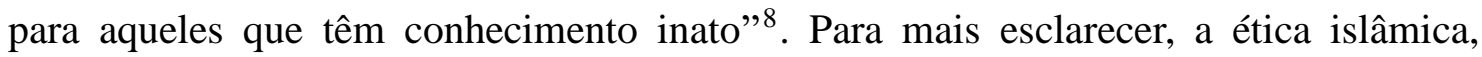

\footnotetext{
${ }^{5}$ her·mé·ti·co (francês hermétique) adjetivo Completamente fechado, cerrado, velado, vedado; que é difícil de compreender, intrincado, obscuro, quase ininteligível. Fonte: Dicionário Priberam da Língua Portuguesa [em linha], 2008-2013. Disponível em:https://www.priberam.pt/dlpo/herm\%C3\%A9tico. Acesso em: 16-05-2018].

${ }^{6}$ Kugle, S. (2010). "Homosexuality in Islam", p. 43. Oneworld, Oxford / Kugle, S. (2010). "Homossexualidade no Islâ", p. 43. Oneworld, Oxford.

${ }^{7}$ Alcorão: 49.13 .

${ }^{8}$ Alcorão: 30.22.
} 
explicada através das metáforas do Alcorão, nos obriga a considerar que cada um de nós obedece a uma forma de determinismo "natural", com base em fatores filogenéticos, ontogenéticos, sociais, emocionais ou intelectuais, conscientes ou inconscientes, cujo pleno domínio pertence à onisciência Divina:

Diga: Deixe cada um agir de acordo com o seu próprio caminho [shakila9], mas seu senhor sabe melhor quem está no caminho com uma melhor orientação. E se eles perguntarem sobre o espírito, diga-lhes: $\mathrm{O}$ espírito vem da ordem do meu Senhor e não foi dado a você um pouco de conhecimento. E se quiséssemos tomar o que te inspiramos você não encontraria ninguém para defender-se contra nós. ${ }^{10}$

Quanto a esta "expressão" individual da nossa "natureza" profunda, o Alcorão não retoma o dogma judaico-cristão do pecado original. A ética islâmica afirma que o ser humano não pode ser considerado responsável por uma "shakila" em que nós, como uma criatura de Deus, nós não temos poder de decisão: “Allah não impõe a ninguém ser um fardo maior que sua força" ${ }^{11}$. O Alcorão também nos lembra que a religião nunca deve, sob nenhuma circunstância, ser aplicada como uma restrição totalitária, seja no espaço privado ou público, mas deve ser considerado como filosofia da vida emancipadora, uma ética humanista e universal:

Não há espaço para coerção na religião. O bom caminho é distinguido claramente da desobediência. Aquele que rejeita falsas divindades ${ }^{12} \mathrm{e}$ acredita em Deus cria o vínculo mais forte, que jamais se rompe. Deus ouve tudo, Ele é Onisciente ${ }^{13}$.

E existe maior coerção do que pedir a um indivíduo que renuncie à sua sexualidade e a todas formas de amor terreno? Deste ponto de vista, o islamismo não é fascismo. Para finalizar, a missão dos profetas de Deus ${ }^{14}$, de acordo com o Alcorão, é praticar a misericórdia e não o serem opressores: "Oh Profeta, nós te enviamos apenas como prova de Nossa Misericórdia para toda a humanidade $[. . .]^{15 "}$. Além disso, a tradição islâmica nos lembraria que nossas ações e sua moralidade devem ser julgadas

\footnotetext{
9 Tradução literal como "natureza" do indivíduo, "disposição natural”, "expressão pessoal”; uma representação da "natureza" humana que inclui, segundo S.Kugle, o seu gênero, a sua sexualidade e que pode ser descrito, como ele vê, como a "psique através da qual o nosso ego se manifesta".

${ }^{10}$ Alcorão: $17.82-83$.

${ }^{11}$ Alcorão: 2.286.

${ }^{12} \mathrm{O}$ fato de adorar o dogma do "Senhor Islam" pode ser considerado como uma maneira inédita, sem precedentes de "idolatria".

${ }^{13}$ Alcorão: 2.256 .

${ }^{14}$ Paz e bençãos estejam com eles.

15 Texto na íntegra - Verso completo: "E não te enviamos, senão como misericórdia para a humanidade, gênios e tudo que existe.” (Alcorão 21:107).
} 
de acordo com nossas intenções sem prejuízo de nosso próximo:

As ações dependem unicamente de sua intenção e cada pessoa receberá sua recompensa de acordo com a intenção com a qual ele realizou suas ações. Portanto, quem migrar para Allah e Seu Mensageiro, a migração será contada por Allah e Seu Mensageiro e, quem migrar para obter riquezas ou se casar com uma mulher, sua migração será para o que ele migrou ${ }^{16}$.

A migração pode ser entendida aqui, no sentido mais amplo da palavra, como um "Retorno para o Divino", como uma metanoia ${ }^{17}$, um processo metacognitivo, uma forma de tawbah ${ }^{18,19}$ espiritual. Essa "migração" nos levaria desta forma, além dos nossos instintos mais primitivos, dos mais "imorais", para retornar à nossa natureza profunda, baseada na bondade moral para nós mesmos e frente aos demais na perspectiva de uma misericórdia universal.

\section{A condenação de práticas "imorais", sexuais ou outras}

Em alguns versos, o Alcorão justapõe o termo shahwa (desejo concupiscente, imoral) com o de bagha (desejo de algo de uma maneira egoísta e irreprimível), e em contraposição a esses termos, o termo $f a d l$ (aproveite as bênçãos concedidas por Deus), o que nos aporta a shukr (gratidão para com o Divino):

É Ele quem colocou o mar à sua disposição, para extrair dele a carne fresca que o alimenta e as jóias que você veste. Observai também, como os barcos navegam pelas ondas e permitem que você vá em busca dos benefícios do divino, e tenhas assim, razões para ser grato ${ }^{20}$.

Em termos gerais, a tradição profética nos convida a pensar que o Profeta dos Muçulmanos, Muhammad (Paz e Bênçãos de Allah estejam com ele), muito provavelmente teria a intenção de nos dar um "modelo de moralidade sexual positiva", mas o fato é que juristas e teólogos clássicos, eram, principalmente, aqueles que tratavam a sexualidade com

\footnotetext{
${ }^{16}$ Alcorão: 21.107.

${ }^{17}$ Alcorão: 2.256 .

18 Termo usado pelos teólogos da libertação cristã nos anos 50. Ver, por exemplo, Gebara, I. (2000). "Teologia da libertação feminina e teologia feminista", em "Teologias da libertação". O Harmattan, Paris.

${ }^{19}$ Tawba (em árabe: توبة alternativamente escrito: tevbe ou turco: tövbe) é uma palavra árabe do Alcorão que significa "um retiro", "um retorno" ou "arrependimento". Tanto o Alcorão quanto o Hadith incorporam a palavra para se referir ao ato de deixar o que Allah proibiu e retornar ao que Ele ordenou. $\mathrm{Na}$ teologia islâmica a palavra denota o ato de estar arrependido pelos seus erros, expiar seus erros, e ter uma forte determinação de abandonar esses erros. Como o Alcorão e o Hadith repetidamente mencionam e enfatizam o ato de reparar os erros de alguém, o tawba é de imensa importância na tradição islâmica. Para um muçulmano é considerado um grande portal para retificar sua vida.

${ }^{20}$ Termo árabe que é frequentemente traduzido como arrependimento, mas epistemologicamente refere-se "ao retorno aos aspectos mais positivos de si mesmo, o retorno a Deus".
} 
reporte negativo" ${ }^{21}$. Assim, o Corão apresenta a sexualidade como uma peça de roupa, em relação ao desfrute de nossos corpos, mas também como uma proteção para nossa dignidade. Este é também o caso de jejum no mês do Ramadã, durante o qual a devoção religiosa é levada ao ponto mais crítico, em teoria, mas nunca em excesso ${ }^{22}$. Em outros versos, o termo usado para se referir a "parceiros" sexuais é a expressão $z a w j^{23}$, que não tem um gênero, portanto, este termo também pode ser aplicado a parceiros e casais heterossexuais ou homossexuais ${ }^{24}$. Com efeito, a ética do Alcorão em questões de sexualidade, assim como nas demais questões, encoraja que as manifestações sejam moderadas em tudo, seja nos relacionamentos heterossexuais ou em outros ${ }^{25}$ ".

Particularmente, o Alcorão cita várias metáforas relacionadas a antigos povos que foram destruídos por sua própria luxúria. Em Sodoma, a esposa de Lot, sobrinha de Abraão, sofreu, de acordo com o Alcorão, o mesmo destino de mulheres e homens representantes deste povo com tradições abomináveis, práticas sociais, políticas e religiosas concupiscentes ${ }^{26,27}$ :

Allah oferece como exemplo aos incrédulos, a esposa de Noé e a de Ló. Ambas se juntaram a dois virtuosos de nossos servos justos e os traíram. Mesmo sendo as esposas deles, não as salvam da punição do Senhor, quando se ouviu dizer: 'Entre ao inferno com os outros condenados ${ }^{28}$.

Além disso, ao longo dos séculos, essa "abominação" não foi mais levada em conta pelo ponto de vista político e nem mesmo pelo ponto de vista social. A sodomia foi associada exclusivamente ao sexo entre homens, seja consensual/consentida ou não. Não vamos esquecer o que meu antigo companheiro de doutorado na EHESS, Mohamed Mezziane ${ }^{29}$ afirmou:

\footnotetext{
${ }^{21}$ Alcorão: 16.14 .

${ }^{22}$ Kugle, op. cit.; p. 49.

${ }^{23} \mathrm{O}$ termo aqui é de fato zawj, que na maioria das vezes, erroneamente, é traduzido como "esposas".

${ }^{24}$ Alcorão: 2.187.

${ }^{25}$ Alcorão: 3.14 .

${ }^{26}$ Alcorão: 30.21 .

${ }^{27}$ Palavra original: Concupiscência. substantivo feminino. cobiça de bens materiais. Anelo de prazeres sensuais. [...] fil no agostinismo, luxúria carnal, desejo libidinoso. Fil no tomismo medieval, desejo de prazer gerado por uma realidade física, material. Teol aspiração humana de bens naturais ou sobrenaturais. Movimento de amor em direção a Deus e aos homens. teol pej. cobiça natural do homem pelos bens terrenos, consequência do pecado original e que produz desordem dos sentidos e da razão (religioso. Cristão). Origem da palavra: ETIM lat. concupiscentĭa, ae 'id.' Fonte: Google-Dicionário.

${ }^{28}$ Alcorão: 3.14 .

${ }^{29}$ Mezziane, M. (2005). "Le sodomite et l'efféminé dans l'Islam du IXe-XIe siècle. Statut juridique et représentations sociales", p. 27. Mémoire de DEA - EHESS, París. Disponible en linea http://www.mohammedmezziane.com/Mezziane-sodomite-effemine.pdf - Mezziane, M. (2005). "O sodomita e efeminado no islamismo do nono século XI. Status legal e representações social”, p. 27. Breve de DEA - EHESS, París. Disponível em: http://www.mohammedmezziane.com/Mezzianesodomite-effemine.pdf. Acesso em: 26/05/2018.
} 
O período mequí corresponde a um contexto em que os muçulmanos pertencentes a minorias, em nível numérico e político, são perseguidos por o mech. As suras deste período distinguem-se por um conteúdo de ordem espiritual, que basicamente eleva o princípio da unidade de Allah, da crença e recomendações ético-morais. Os versos do Alcorão, que lidam com as práticas sexuais do povo de Lot, pertencem a este período de $\mathrm{Meca}^{30,31}$.

\section{A sodomia em suas origens: a proibição de violações na forma de rituais}

Tendo em vista o contexto historiográfico e os princípios axiológicos que acabamos de descrever, o que dizer sobre a representação da sodomia no Alcorão? Primeiro elemento: o termo "homossexualidade" 32 em nenhum momento é citado no Alcorão.

\section{1 - O Alcorão descreve muito claramente, a "abominação" do povo de Lot como} um evento sem precedentes. Muitas vezes, o verso citado anteriormente é tirado de seu contexto, o que leva facilmente ao desvio semântico. Vamos citar este versículo na sua totalidade:

E [LEMBRE-SE] de Ló, quando ele disse ao seu povo: 'Você se entrega a uma abominação que ninguém no mundo tenha cometido antes? Você vai para os homens com desejo, em vez de (ir às) mulheres: você é, na verdade, um povo desenfreado!'. A única resposta de seu povo foi dizer: 'Leve-os para fora de sua terra! Eles são, em verdade, um povo que finge ser puro! E então nós salvamos ele e sua família - exceto sua esposa, que foi uma das que pereceram'.

\footnotetext{
${ }^{30}$ Ele nasceu em Casablanca em 1963 e ingressou na Act Up-Paris em 1997 como militante e depois como coordenador da Comissão de Investigações. Em 2002 graduou-se na EHESS-Paris em Antropologia Histórica. Investigou o período medieval andaluz com a "Monografia de um voyageur arabe du XIIe siècle" - "uma monografia de um viajante árabe do século XII" (Ibn Jubayr). Entre 2003 e 2005, como parte de seu doutorado especializado no período muçulmano medieval, realiza pesquisas sobre o vínculo estabelecido por juristas muçulmanos entre masculinidade, sexualidade e sodomia. Nas suas Memórias sobre Ibn Jubayr, este trabalho foi dirigido por Jocelyne Dakhlia. Desde 2005 ele foi um estudante de doutorado na EHESS sob a direção de Jocelyne Dakhlia e se juntou ao CDH. Sua pesquisa tratou do discurso sobre masculinidade, sexualidade e homossexualidade, mas em períodos modernos e contemporâneos no Oriente Médio. Mohammed Mezziane morreu em 2014, antes de concluir a redação de seu doutorado. No link a seguir, podemos ver como a mídia faz esse tributo: http://yagg.com/2014/09/05/disparition-de-mohammed-mezziane-specialiste-des-questionshomosexuelles-dans-lemonde-arabe/. Acesso em: 26/05/2018.

${ }^{31}$ Alcorão: 66.10.

${ }^{32}$ Em árabe seria al-mithliya al-djansia ("mesmice" sexual) ou, mais pejorativamente, al-shoudoud aldjansi ("extremismo sexual"). Além disso, como Joseph Massad aponta: "É importante enfatizar que não apenas o conceito de homossexualidade não existia em si mesmo, mas ainda que, se um desejo masculino "homossexual" existisse como tal, não era o tema principal do discurso. O que foi discutido foi "amor por meninos" e "sodomia"; nenhum desses termos indica exclusividade. Desiring Arabs (2007), Universidade de Chicago Press. Além disso, é, sem dúvida, Khaled Rouayheb quem melhor expressa essas mutações transgeográficas sob influência colonial ocidental, em termos de representação das sexualidades: "A opinião geral que se fez sobre as relações homossexuais [dentro das Sociedades Árabes-Muçulmanas], um pecado semelhante ao roubo ou ao adultério, deu lugar à ideia de que eles eram indicativo de uma constituição psicológica ou fisiológica anormal", Rouayheb, K. (2010). "L'amour des garçons en pays arabo-islamique: XVIe-XVIIIe siècle". Epel, Paris.
} 
Aqui encontramos a referência à esposa de Lot, que perece devido a sua participação em práticas desumanas e lascivas de sua terra adotiva: sodomia, as violações nos rituais dentro do templo da deusa $\operatorname{Ishtar}^{33}$, banditismo ${ }^{34}$. Além disso, e a menos que acreditemos que (a terra é plana e) que a homossexualidade foi criada para o povo de Ló cinco mil anos atrás em Sodoma e Gomorra, (o que alguns pregadores wahhabis promovem e utilizam em seus argumentos com o fim de manipular), não é possível conceber ideia de que se trata da homossexualidade.

2 - Também temos outro verso que claramente confirma que esses patriarcas sodomitas não eram homossexuais, como a entendemos hoje, mas esses criminosos achavam que eles tinham o direito de ter o direito sobre aqueles que consideravam subordinados ao seu poder sem o consentimento daqueles ou daquelas ${ }^{35}$ :

Imediatamente, os homens de seu povo, acostumados a cometer o pior das abominações, se apressaram para casa. 'Oh povo meu!', disse Lot, 'aqui estão minhas filhas, elas são melhores para vocês! Sejam, pois, consciente de Deus e não me desenhorem entre meus convidados. Não há entre vocês um único homem sensato?'36

Não vamos ser demasiadamente duros com o profeta $\operatorname{Lot}^{37}$ : queria ele oferecer, realmente, suas filhas como um sacrifício? Sem dúvida, ele queria fazer seus atacantes entenderem que violentar os viajantes que se encontravam de passagem, eles que são como os anjos que estão indo entregar uma mensagem Divina para Sodoma, era pior do que suas práticas em rituais de estupro. Esses atos sexuais coercitivos, como Heródoto os descreveu, são impostos com mais frequência entre membros mais jovens do povo, sejam eles homens ou mulheres ${ }^{38}$. Este verso confirma que os sodomitas não eram homossexuais, caso contrário Ló não teria pensado em propor-lhes que se envolvessem

\footnotetext{
${ }^{33}$ Provavelmente as práticas sexuais que o antigo historiador Heródoto descreveu da seguinte forma: “[...] Uma vez em sua vida, a tradição é sentar no templo do amor [dedicado à deusa Ishtar] e ter ... encontros com um estranho ... os homens passam e fazem sua escolha. Não importa quanto ele tenha de dinheiro, a mulher nunca se recusa, porque seria um pecado, porque o dinheiro era sagrado de acordo com a tradição da época". De boa fé, estas não foram práticas homossexuais como tal. Estas são práticas sexuais violentas e dominação que podem ser realcionadas à prostituição, sem consentimento e em público, ou violações em forma de rituais. Veja Dening, S. (1996). "The Mythology of Sex", capítulo 3. Macmillan General Reference, Nova York.

${ }^{34}$ Veja por exemplo: "E como é possível que você cometa esses atos repreensíveis em suas reuniões? Porém, a única resposta de seu povo foi dizer: 'Faça a punição de Deus cair sobre nós, se você é da verdade'!" Alcorão: 29:29.

${ }^{35}$ No texto original a frase final do texto diz: "[...]el derecho de pernada sobre aquellos y aquellas que consideraban como subordinados a su poder sin compartir" / o direito de partido sobre aqueles e aqueles que consideraram subordinado ao seu poder sem compartilhar.

${ }^{36}$ Alcorão: 11.78 .

${ }^{37} \mathrm{~A}$ paz e as bênçãos de Allah estejam com ele.

${ }^{38}$ Kugle, op. Cit.; p. 56.
} 
com aquelas jovens garotas. $\mathrm{O}$ profeta ${ }^{39}$, de acordo com certa versão da tradição, teria proibido esse tipo de práticas pedófilas, patriarcais e não consentidas. Ele denunciou claramente que os homens de sua aldeia estavam fazendo sexo anal com um homem jovem e, mais tarde, se casavam com a mãe desse jovem. Nós temos aqui uma distinção clara e inequívoca da sodomia violenta e sexo anal consentido ${ }^{40}$.

3 - O Corão também denuncia esses patriarcas criminosos que querem estuprar homens estrangeiros a fim de menosprezá-los, enquanto eles estão comprometidos com seu relacionamento marital heterossexual: "E você se afasta das esposas que seu Sustentador criou para você? Sim, você é um povo que transgride todos os limites do certo! $^{41}$ ". Aqui, o modo gramatical usado pelo Alcorão é inequívoco: al-nisa se refere a mulheres em particular, não as mulheres em geral. Esses estupradores sodomitas eram, portanto, casados. O que torna sua concupiscência ainda mais abominável: não se trata, para eles, de satisfazer uma necessidade natural, superar uma frustração sexual irreprimível por meio de práticas que não seriam menos criminosas, mas para apropriarse da dignidade dos outros através de um estupro; uma humanidade oferecida como sacrifício no altar de sua sede de poder, reivindicando um culto pagão.

4 - Além disso, acrescento que o Alcorão nunca ordena que os muçulmanos sigam as regras religiosas de outros povos que vieram antes de nós. "Para você, sua religião e a minha para mim" ${ }^{42}$ : A cada um, suas práticas e suas tradições. A primazia é concedida à ética universalista e humanista, qualquer que seja o caminho ${ }^{43}$ (shari ${ }^{, 44}$ ) que facilite o progresso em direção à iluminação. Em outras palavras, mesmo que a homossexualidade e o que teria sido condenada pelo profeta $\operatorname{Lot}^{45}$, nada forçaria os muçulmanos a se ajustar a esses julgamentos, já que o Alcorão nos diz o seguinte:

E [eu vim] ${ }^{46}$ para confirmar a verdade do que ainda está na Torah e para fazer lícito algumas coisas que [antes] foram proibidas para você. E eu vim para trazer uma mensagem do seu Sustentador; esteja, portanto, consciente de Deus e me obedeça ${ }^{47}$. Por exemplo, o apedrejamento de

\footnotetext{
${ }^{39} \mathrm{~A}$ paz e as bênçãos de Allah estejam com ele

40 Bukhari (5105) livro de casamento (Vol. 1, Livro 62, Hadith 41). Disponível online https://sunnah.com/bukhari/67. Acesso em: 26/05/2018.

${ }^{41}$ Alcorão: 26.166.

${ }^{42}$ Alcorão: 109.6.

${ }^{43}$ No texto em espanhol: 'a via' (shari').

44 "SHARI": A sua visão de um estado islâmico ideal é de um estado em que ashari'ah lei islâmica, forma a base para a autoridade política; "via"; "caminho". Fonte: https://www.linguee.com.br/portugues-ingles/traducao/shari.html. Acesso em: 26/05/2018.

${ }^{45}$ La paz y las bendiciones de Allah sean con él.

${ }^{46}$ Issa (Jesus) A paz e as bênçãos de Allah estejam com ele.

${ }^{47}$ Alcorão: 3.50 .
} 
crianças que não obedecem aos pais ${ }^{48}$, citado na Bíblia, não é uma prática coletada no Alcorão.

5 - Por fim, dentro da mesma tradição islâmica, certas recomendações éticolegais foram substituídas por outros, adaptando-se a mudanças nas contingências sociopolíticas e as quais a comunidade dos primeiros crentes tiveram e puderam se adaptar. O Alcorão chama isso de $a l$-nask $h^{49}$ : a revogação de uma opinião teológica em relação a outra. O encontramos entre as tradições monoteístas, mas também dentro da mesma tradição profética: "Se cancelarmos uma mensagem ou fizermos com que ela seja esquecida, a substituímos por uma melhor ou semelhante. Você não sabe que Deus tem o poder de dispor de alguma coisa?" 50

\section{O Profeta era homofóbico e transfóbico?}

1 - Um verso muito bonito do Alcorão apresenta todas as possíveis interseções entre esses dois fatores: gênero e sexualidade. Não como um erro da natureza, mas como intenção explícita do Divino, como uma demonstração de todo o alcance do poder do Eterno ${ }^{51}$ :

De Deus é apenas o domínio sobre os céus e a terra. Acredite no que ele quer: dá descendentes do sexo feminino a quem eles querem, e descendentes masculinos a quem ele quer ou dá filhos e filhas a quem ele quer, e faz quem ele quer estéril: ele/ela é, de fato, onisciente, infinito em seu poder..$^{52}$

\footnotetext{
${ }^{48}$ Deuteronômio (21:18): "Se um homem tem um filho indisciplinado e rebelde, que não ouve a voz de seu pai e de sua mãe, e não os obedece mesmo depois de tê-lo castigado, o pai e a mãe o levarão aos anciãos de sua cidade e na porta do lugar onde moram. Eles dirão aos anciãos de sua cidade: 'Aqui está nosso filho que é indisciplinado e rebelde, que não ouve a nossa voz e se entrega a excessos e embriaguez'. E os homens de sua cidade o apedrejarão e ele morrerá, assim removerás o mal do meio de ti, para que todo o Israel ouça e tema".

${ }^{49}$ Naskh lexicamente significa substituir algo por outra coisa. Na terminologia religiosa, significa a substituição de um decreto religioso e ordem relacionada à adoração ou uma transação por outro decreto e ordem posterior; Este ato é chamado naskh (abrogação), o novo decreto é chamado nasikh (abrogador) e o verso cuja validade foi anulada é chamado mansukh (revogada), que não é mais válido. Naskh não está em questão em crenças básicas, notícias e histórias. Está em questão em ordens e proibições. Imam Qurtubi afirma o seguinte sobre o assunto: "Todos os estudiosos devem conhecer naskh com suas evidências. Somente pessoas sem cérebro e ignorantes rejeitam a naskh. Deduzir um decreto a partir dos versos do decreto no Alcorão e saber halais e harams só pode ser possível conhecendo-se naskh. Aqueles que não sabem disso são privados do conhecimento e que existe naskh no Alcorão, como todos os estudiosos islâmicos concordam com isso". É afirmado no verso 106 do capítulo de al-Baqara que naskh existe no Alcorão da seguinte forma: "Nenhuma de nossas revelações revogamos ou esquecemos, mas substituímos por algo melhor ou semelhante...". Texto-definição na íntegra pode ser estudado em 'Revogação (Nask) no Alcorão e a sabedoria por trás da revogação'. Disponível em: https://translate.google.com.br/translate?hl=pt-BR\&sl=en\&u=https://questionsonislam.com article/abrogation-naskh-quran-and-wisdom-behind-abrogation\&prev=search. Acesso em: 26/05/2018. ${ }^{50}$ Alcorão: 2.107.

${ }^{51}$ No texto em espanhol 'o Divino' está descrito como 'ele/ela', não exclusivo da natureza masculina.

52 Alcorão: 42.49-50.
} 
Além da diversidade de gêneros e sexualidades, este versículo evoca a possibilidade de que um indivíduo ser "masculino e feminino": seriam pessoas que chamaríamos hoje intersexuais? Aqueles que não estão comprometidos com a dinâmica da "reprodução" ('aqim). Eles também são mencionados aqui, como a maioria dos casais de gays e lésbicas.

2 - Finalmente, este versículo faz uma distinção clara e precisa entre esses dois conceitos de "natureza" e "parentesco". Por um lado, invocando a diversidade daqueles que podem ou não ter acesso à filiação, ao mesmo tempo em que especifica quem escolhe (como foi o caso de João Batista ${ }^{53}$ ) não ter filhos ou mesmo renunciar de uma vida conjugal, não são culpados de nenhum crime ${ }^{54}$.

3 - De acordo com a tradição dos hadiths, o Profeta dos Muçulmanos ${ }^{55}$, cuja ética pessoal corresponderia em todos os aspectos ao Alcorão (de acordo com sua própria esposa 'Aicha ${ }^{56}$ ), estava com um homem na rua quando um terceiro homem chegou, o primeiro disse:

'Oh, Mensageiro de Deus, amo este homem!'57. Para qual o Mensageiro de Deus respondeu: 'Você compartilhou seus sentimentos com ele?' Ele respondeu: 'Não'. O Profeta ${ }^{58}$ então lhe disse: 'Diga a ele'. E o homem olhou para o seu parceiro e disse: 'Te amo pela graça de Allah'. E este último respondeu: 'Que Allah te ame pelo amor que sentes por mim, pela graça de Deus' ${ }^{59}$.

O Profeta ${ }^{60}$ teria encorajado um homem a declarar seu amor por outro ee ele fosse um líder misógino e homofóbico, como descrito por muitos muçulmanos dogmáticos com identidades fascistas? Pelo contrário, um homem assim, segundo o que está descrito pela tradição árabe-islâmica, teria permitido a sentença de morte de dois homens que se amam?

4 - Para responder a esta questão aos juristas e às juristas muçulmanos foram desenvolvidas algumas técnicas mais ou menos elaboradas para estabelecer a rastreabilidade de uma tradição profética, com o objetivo de estabelecer, por assim dizer, o risco de que esta ou aquela tradição seja considerada como verdadeira ou

\footnotetext{
${ }^{53}$ Alcorão: 3.39 .

${ }^{54}$ Alcorão: 24.60.

${ }^{55}$ A paz e as bênçãos de Allah estejam com ele.

56 Segundo Aicha: "Seu comportamento era o Alcorão" (Autenticado pelo Sheikh Al Albani, relatado por Abu Dawud 40/2, An-Nassai199 / 3, Ad-darimi 345/1).

${ }^{57}$ Alcorão: 42.49-50.

${ }^{58}$ A paz e as bênçãos de Allah estejam com ele.

${ }^{59}$ Abu Dawud: livro 42, capítulo 11, hadith 5127.

${ }^{60}$ A paz e as bênçãos de Allah estejam com ele.
} 
apócrifa. A maioria das publicações sobre o assunto trata brevemente dessas regras e, portanto, é uma boa ideia parar por um momento. Os dois principais elementos estudados pelos estudiosos e pelas estudiosas do hadith em todos os séculos e até a atualidade são a matança: o conteúdo da tradição oral, e o $i s n a d^{61}$ : a cadeia de pessoas que estavam coletando e transmitindo essa tradição oral de geração em geração.

5 - A dificuldade aqui reside no fato de que o conteúdo, o matar, muitas vezes varia da pessoa que recolhe o hadith para outro (é a síndrome do "telefone árabe") e nem sempre é sobre personalidades com uma reputação irrepreensível. Este é o caso, em particular, dos hadiths que condenam direta ou indiretamente a homossexualidade. Alguns companheiros próximos como 'Omar, o segundo califa do Islã, ou 'Aicha, a esposa do Profeta ${ }^{62}$, afirmaram que alguns muçulmanos difundem informações falsas em nome do Profeta dentro da comunidade de crentes.

6 - No entanto, uma vez que uma tradição apócrifa é atribuída ao Profeta ${ }^{63}$, o mal já está feito e séculos mais tarde ainda são encontrados em algumas coleções de hadiths. Seria o orientalista alemão, Joseph Schacht ${ }^{64}$ o primeiro a afirmar que hadiths, com um corpus padronizado, foram escritos bem mais tarde, por volta do século II da era islâmica. Assim, eles representam mais as opiniões e moral puritana dos Imames e Muftis que eles estabeleceram como dogma islâmico padronizado do que a verdadeira

\footnotetext{
${ }^{61}$ Isnad - Isnād, (do árabe sanad, "apoio"), no Islã, uma lista de autoridades que transmitiram um relatório (hadith) de uma declaração, ação ou aprovação de Muhammad, um de seus Companheiros (Sahābah), ou de uma autoridade posterior (tabi) sua confiabilidade determina a validade de um hadīth. O isnād precede o texto atual (matn) e assume a forma: "Foi relatado a mim por A sob a autoridade de B sobre a autoridade de C sobre a autoridade de D (geralmente um Companheiro do Profeta) que Maomé disse. [...]". Durante a vida de Maomé e após a sua morte, hadīths eram geralmente citados pelos seus companheiros e contemporâneos e não eram prefaciados pelos isnāds; somente após uma ou duas gerações (c. AD 700) o isnād pareceu aumentar o peso de seu texto. No século $2 \mathrm{dC}$ (depois de 720 DC), quando o exemplo do Profeta, tal como corporificado em hadith - em vez de costumes locais, desenvolvidos em comunidades muçulmanas - foi estabelecido como norma (sunnah) para um modo de vida islâmico, criação de hadīths, todos "substanciados" e por elaborados isnāds, como resultaram. Como hadīths era a base de praticamente todo o conhecimento islâmico, especialmente a exegese corânica ( $\operatorname{tafsīr}$ ) e a teoria jurídica (fiqh), os estudiosos muçulmanos tinham que determinar cientificamente quais deles eram autênticos. Isso foi feito por um exame minucioso dos isnād, classificando cada according adīth (de acordo com adīth) $e$ de acordo com a integridade de sua cadeia de transmissores, a confiabilidade e ortodoxia de suas autoridades (ver 'ilm al-ḥadīth). As primeiras compilações dos mais confiáveis hadīths (conhecidos como musnads) foram até arranjados por isnād, isto é, classificados de acordo com o Companheiro de Muhammad a quem foram atribuídos. O mais notável destes foi o musnad de Aḥmad ibn Hanbal (m. 855), incorporando cerca de 29.000 tradições. Musnads provou ser difícil de usar eficientemente, e compilações posteriores, conhecidas como mus annaf, agruparam hadìths de acordo com o assunto. Fonte Google-Encyclopaedia Britannica. Disponível em <https://www.britannica.com/topic/isnad>. Acesso em 26/05/2018.

${ }^{62}$ A paz e as bênçãos de Allah estejam com ele.

${ }^{63}$ Supra.

${ }^{64}$ Islamólogo germano-britânico (1902-1969).
} 
ética do Alcorão, incorporada em seu tempo pelo profeta dos muçulmanos ${ }^{65}$. Estes Imames e Muftis dos primeiros séculos do Islã lutaram contra o implacável interrogatório emergente do dogma islâmico, e mais ainda contra a tentação de uma guerra civil entre os muçulmanos.

\section{Hadiths homofóbicos em tempos de crise político-identitárias}

1 - Este é especialmente o caso da tradição oral segundo a qual nos é dito o seguinte: "Quando um homem penetra outro homem, os anjos ficam alarmados, lançam um grito que atinge seu Senhor [...]", em outra versão seria até dito que "o trono do misericordioso é abalado ${ }^{66}$ ". Mas então, como poderiam dois seres humanos agitar o trono, metafórico, do eterno? O Ibn Al-Qayyim Al-Jawziyya ${ }^{67}$, muito famoso, embora muito conservador (morreu em 1350) considerou, também, que era muito improvável que este hadith fosse autêntico ${ }^{68}$. Muhammad Patani (falecido em 1578), apelidado no sul da Ásia como “o rei dos sábios dos hadiths", nos pediu: "prestem atenção às mentiras na questão dos hadiths ${ }^{69}$ ".

2 - Muitos estudiosos e renomados no estudo de hadith afirmaram que essa tradição teria sido colocada em circulação após a morte do profeta $^{70}$. No entanto, eles não poderiam eliminar essas tradições apócrifas, falsas e com fobias sociais inconscientes. Prova disso é que, em 1960, Muftí Zafeeruddin, um índio simpatizante do Deobandism, publicou em Urdu, um panfleto particularmente amargo contra os "efeminados" e homens que amam outros homens, independentemente do caráter apócrifo de tais tradições ${ }^{71}$. Mas outro homem sábio, o famoso Sr. Patani, classifica essa outra tradição entre os apócrifos: "os sodomitas [lutiyyun ${ }^{72}$ ] serão ressuscitados no Dia do Juízo Final como macacos e porcos"73. No entanto, uma vez mais, Mufti Zafeeruddin cita esta tradição tirada de uma ideologia homofóbica e transfóbica, sem fazer nenhum caso de sua autenticidade.

\footnotetext{
${ }^{65}$ A paz e as bênçãos de Allah estejam com ele.

${ }^{66}$ No texto original: "[...] El trono Del misericordioso es sacudido".

${ }^{67}$ Jurista e mufti muçulmano sunita, tradição Hanbali, natural de Damasco (1292-1350).

${ }^{68}$ Rawdat al-muhibbin, p. 400.

69 Tadhkirat al-Mawdu'at, p. 171.

${ }^{70}$ A paz e as bênçãos de Allah estejam com ele.

${ }^{71}$ Zafeerudin (1998). "Islã sobre a homossexualidade", p. 78. Darul Ishaat, Paquistão.

72 " [...] A terminologia na língua foi adaptada e hoje se distingue entre lutiyyun (sodomita) e mithliyyn AL-jinsiyya (homossexual)". Com muita dificuldade encontramos a definição para a expressão Lutiyyn e sua utilização* no texto completo, a seguir, e no estudo que pode ser apreciado na íntegra em "Homossexualidade no Oriente Médio: a região não entende". Itxaso Dominguez de Olazábal. https://laverdadofende.blog/2015/09/22/ homosexualidad-en-oriente-medio-la-region-no-entiende-itxasodominguez-de-olazabal/. Acesso em: 30/05/2018;

${ }^{73}$ Patani, op. cit., p. 171.
} 
3 - Sr. Patani rejeitou outros hadiths homofóbicos, com toda honestidade ${ }^{74}$, como aquele que diz: "Allah amaldiçoa aqueles que desejam um jovem escravo $\left[\right.$ ghulam $\left.^{75}\right]$ com concupiscência. Se acaricia-lo com luxúria, Allah nunca voltará a aceitar suas orações novamente. Se o beijar, será chicoteado pelas chamas do inferno no Dia do Jizo. Se fornica com ele, então Allah o lançará nas chamas do inferno ${ }^{76}$ ". O Sr. Patani pensa o mesmo deste outro hadith, que também é apócrifo e fabricado: "Não há um jovem pré-adolescente [amrad] mais culpado do que aquele que se deixa ter prazer por trás ${ }^{77}$ ”. Ou este outro: “Aquele que recebe prazer de trás sete vezes, Allah muda seu desejo pelo prazer que é recebido pela frente pelo prazer que recebe de trás ${ }^{78}$ ". Sobre aqueles que inventaram ahadith para justificar seus medos mais reprimidos, Ibn AlQiyaam AlJawzi disse: “Entre aqueles que fabricaram hadiths e que mentiram, há aqueles que são oprimidos pelo zelo e dão pouca importância à boa memorização [...]. Eu não vi ninguém que mentisse mais sobre os hadiths do que aqueles que são conhecidos por sua piedade e zelo ascético ${ }^{79}$ ".

\section{Status do "mukhannazun"80": "afeminado", transgêneros ou gays?}

Aqueles descritos em árabe como mukhanathun (“efeminados"), são frequentemente associados com a homossexualidade, embora seja mais apropriado considerá-los, tendo em vista a tradição islâmica na sua junção, como um todo, como os que se chamariam atualmente transgênero ${ }^{81}$. É assim que Al-Bukhari, um dos estudiosos mais famosos de Hadith, integra essas tradições baseando-se na forma com a

\footnotetext{
${ }^{74}$ Desde o nosso conhecimento, Ele (Allah) não estava pessoalmente preocupado com esses debates.

75 Ghulam (em árabe: غلام) é uma palavra árabe que significa "servo", "menino", "juventude". É usado para descrever jovens servos no paraíso. Ele também é usado para se referir a soldados-escravos nos impácidos Abássidas, Otomanos, Safávidas e, em menor medida, nos impérios mongóis, como descrito no artigo Ghilman, que é a forma plural da palavra. Pode ser usado como primeiro elemento de um nome masculino muçulmano, que significa "servo de..." ou, nos tempos modernos, como um sobrenome independente. Fonte: Google-Wikipedia. Disponível em https://en.wikipedia.org/wiki/Ghulam. Acesso em 30/05/2018.

${ }^{76}$ Desde o nosso conhecimento, Ele (Allah) não estava pessoalmente preocupado com esses debates.

${ }^{77}$ Idem.

${ }^{78}$ Idem.

${ }^{79}$ Op. Cit., P. 8.

${ }^{80}$ Mukhannazun (em árabe)مخنثون: "efeminado", "homens que se parecem com mulheres", no singular: mukhannath) é, no árabe clássico, uma velha concepção de mulheres transgênero que, quando chegou a hora, foram forçadas a castrar-se. Houve menção de "mukhannathun" em hadiths e estudiosos do Islã. Além dos textos religiosos, eles estão fortemente associados à música e ao entretenimento. Khanit é um termo vernacular árabe usado em Omã e nos países da Península Arábica para designar o papel de gênero atribuído a homens que funcionam sexualmente e, de certa forma, socialmente, como mulheres. A palavra está intimamente relacionada com o termo "mukhannath".

${ }^{81}$ Além disso, a raiz árabe Khuntha refere-se aqui ao gênero feminino, e não à sexualidade. O prefixo árabe invoca gramaticalmente a pessoa que incorpora o conceito antes do radical a partir do qual este prefixo é colocado.
} 
qual o Profeta ${ }^{82}$ observou os mukhanathun, em sua seção sobre adultério e fornicação. Por quê?

1 - Um desses hadiths que Al-Bukhari cita em três versões diferentes nos mostra como em uma noite antes de uma campanha militar importante para a sobrevivência da comunidade dos Muçulmanos, um homem chamado Hit, servindo a Umm Salam, uma das esposas do Profeta ${ }^{83}$ disse a Abdullah, o irmão de Umm Salam: “Oh 'Abdullah, se Deus te conceder a vitória amanhã em Ta'if ${ }^{84}$, procure favores" da filha de Ghaylan, porque ela te enfrenta com quatro te retorna com oito ${ }^{85}$ !" Ao ouvir isso, o Profeta ${ }^{86}$ disse: "Não deixe que essas pessoas cheguem perto de você" 87.

Aqueles entre os muçulmanos mais dogmáticos, que tentariam justificar sua homofobia e transfobia, ignoram completamente o contexto de tal evento, indispensável para entender a Ética islâmica da sexualidade. Não é o fato de que os mukhanathun são efeminados, o que teria provocado este julgamento por parte do $\operatorname{Profet}^{88}$, mas o fato de que um deles, ao se aproximar das mulheres do Profeta, parece ter mostrado indiferença, sexualmente falando, em relação às mulheres, o que teria causado desconfiança nesse último. Mesmo Hit foi expulso junto com seu próprio companheiro, chamado Mati', que também foi acusado por alguns de ser o único culpado ${ }^{89}$.

2 - Adicionamos também outra versão deste mesmo evento ${ }^{90}$ onde Aicha, a mais próxima e a mais erudita das mulheres do Profeta ${ }^{91}$, especifica que Hit não deveria ter nenhum desejo para as mulheres: min ghayr uli irba ${ }^{92,93}$. Esta é a mesma expressão que encontramos no Alcorão (24.31) e será citado mais a frente, onde muitos homens são descritos, hoje considerados como homossexuais ou transgêneros: sem desejo para com

\footnotetext{
${ }^{82}$ A paz e as bênçãos de Allah estejam com ele.

${ }^{83}$ A paz e as bênçãos de Allah estejam com ele.

${ }^{84}$ Não muito longe de Medina, uma cidade liderada naquela época por uma das tribos mais resistentes à Mensagem do Profeta.

${ }^{85}$ Se a moda de hoje é ser magra, naquele momento era generosidade que preferiam os homens.

${ }^{86}$ A paz e as bênçãos de Allah estejam com ele.

${ }^{87}$ Al-Bukhari, op. cit. ; Livro 77, capítulo 62, Hadith 5948.

${ }^{88}$ A paz e as bênçãos de Allah estejam com ele.

${ }^{89} \mathrm{O}$ companheiro de Hit, às vezes chamado Mati ou Mati'a (que significa "anonist", homem ou mulher, de acordo com as versões). Veja por exemplo Al-shafi'i, Al-Umm; 5369-370.

${ }^{90}$ Muslim, op. cit.; Livro 40, Capítulo 13, Hadith 5820.

${ }^{91}$ A paz e as bênçãos de Allah estejam com ele.

92 NOTA EXPLICATIVA: “[...] Ao explicar o hadith de Hīt, Ibn AL-Jawzī escreve, a respeito do mukhannat congênito: 'Dizem [que são]' aqueles que não possuem desejo sexual (ghayr ulī '1-irba), significando necessidade para as mulheres. [...] - excluindo o desejo sexual por mulheres, nas não necessariamente por homens". Fonte: Google-"E o macho não é como a fêmea: islamismo sunita e nãoconformidade de gênero - o que o islã sunita diz sobre os indivíduos atípicos de gênero". Texto-estudo na íntrega disponível em: https://muslimmatters.org/2017/07/24/and-the-male-is-not-like-the-female-sunniislam-and-gender-nonconformity/. Acesso em: 31/05/2018.

${ }^{93}$ Alcorão: 24.31 .
} 
as mulheres. Além disso, esses homens desfrutaram de um status especial na casa do Profeta ${ }^{94}$ entre seus filhos e suas esposas. As mulheres não colocavam o véu diante deles. Este evento tende a demonstrar claramente que os primeiros muçulmanos tinham um profundo conhecimento de sexo, gênero e sexualidade: um homem afeminado não era, nesse caso, exclusivamente, considerado gay, transidentitário, ou até mesmo sexualmente impotente, e vice-versa. Entretanto, outros que relataram esse mesmo evento, acrescentaram um toque particularmente homofóbico e transfóbico sem que isso estivesse diretamente relacionado às palavras do Profeta ${ }^{95}$, para desacreditar as mulheres mais próximas dele. Uma dessas versões nos diz, por exemplo: "O Profeta 96 amaldiçoou os homens efeminados (al-mukhanathin min al-rijal) e as mulheres masculinas (al-mutarajjulat min al-nisa) e disse: "Tire-os de suas moradas"97.

3 - Essas tradições deixam de mencionar o contexto. Além disso, essa omissão ${ }^{98}$, referindo-se ao mesmo evento, sugere que todas as pessoas andróginas ou transgêneros são supostamente malditas, para que assim sejam excluídas de suas casas. É mais característico da discriminação do que o julgamento de um grupo de indivíduos, considerados “infra-humanos ${ }^{99 ", ~ d e v i d o ~ a ̀ s ~ m a ́ s ~ a c ̧ o ̃ e s ~ d e ~ u m ~ e n t r e ~ o s ~ d e m a i s . ~ M e s m o ~}$ com a mesma ideia homofóbica e transfóbica, outra versão deste mesmo evento vai além, afirmando que: “O Profeta ${ }^{100}$ amaldiçoou homens que se assemelham a mulheres (almutashabihun bil-nisa) e mulheres que se assemelham aos homens (al-mutashabihat bil-rijjal)". Assim, após uma sucessão de deformações sintáticas e distorções semânticas, como um evento isolado se tornou discriminação, considerada até mesmo como uma obrigação legal para todos aqueles que não estão satisfeitos com a ideia de que uma minoria de homens heterossexuais têm sexualidades e gêneros heteronormativos ou uma determinada separação de sexos.

4 - A homofobia e a transfobia provavelmente sempre existiram entre o fascínio e o desgosto. Alguns dos companheiros do Profeta ${ }^{101}$ não são exceção a essa regra universal de discriminação contra a maioria das minorias subordinadas, as que têm sexualidade ou alternativa de gênero ao modelo reprodutivo, natalista e patriarcal. No

\footnotetext{
${ }^{94}$ A paz e as bênçãos de Allah estejam com ele.

${ }^{95}$ A paz e as bênçãos de Allah estejam com ele.

${ }^{96}$ Supra.

${ }^{97}$ Al-Bukhari, op. cit. ; livro 77, capítulo 62, hadith 5947.

${ }^{98}$ No texto original: "[...] Além disso, essa morte [...]."

${ }^{99}$ Ver por ejemplo: Zahed, 1. (2017). "LGBTs Muçulmanos: do armário ao iluminismo, enfrentando o obscurantismo e o homonacionalismo". CALEM, Marseilla.

${ }^{100}$ A paz e as bênçãos de Allah estejam com ele.

${ }^{101}$ A paz e as bênçãos de Allah estejam com ele.
} 
entanto, de acordo com uma tradição que, novamente, refere-se ao mesmo evento (como não, ...), depois que Hit foi expulso de Meca, ele foi autorizado a voltar lá duas vezes por semana para pedir comida. Um dia, um dos companheiros do Profeta ${ }^{102}$, vendo suas mãos cobertas com henna - uma prática reservada exclusivamente para mulheres, segundo alguns - propõe executá-lo, sob o pretexto de que a atitude de Hit perturbou a "comunidade das mulheres". Foi esta uma forma modesta e desviada de condenar qualquer serviço sexual que Hit pudesse prodigar como remuneração ${ }^{103}$ ?

Sejam práticas sociais desconfortáveis, desde o ponto de vista sexista, machista, patriarcal ou mesmo da revelação da privacidade das mulheres na frente de outros homens e, portanto, caiam na armadilha do desejo concupiscente em relação a elas, o fato é que esse hadith nos confirma que o Profeta ${ }^{104}$ não só teria se recusado a atacar um homem afeminado com uma sexualidade indeterminada, com certeza até hoje, mas também defendeu proativamente seus direitos dizendo: "Fui proibido de matar àqueles que rezam" 105 .

5 - Para estes beduínos do deserto, a oração era um sinal da unicidade de Deus que se reflete em nossa humanidade: em posição, ombro a ombro, orando juntos, independentemente de sua etnia, gênero ou sexualidade. Além disso, o Profeta não disse que Hit era muçulmano, mas simplesmente, que ele invocou a oração. Num sentido amplo, oração, contemplação ou meditação são os denominadores comuns mais básicos entre todas as nossas representações de espiritualidade. O Profeta dos Muçulmanos, com toda a probabilidade, reconheceu uma igualdade de princípios entre todos, independentemente da sua crença ${ }^{106}$, seu gênero ou sua sexualidade. Portanto, é muito provável que todos os hadiths que condenem, direta ou indiretamente, homossexualidade e transidentidade, sejam hadiths apócrifos. Estes hadiths homofóbicos e transfóbicos estão em total contradição com a ética islâmica encarnada pelo Profeta, que viveu sob seu próprio teto, entre suas esposas, seus filhos ... e seus afeminados. Não haveria hadith, mesmo apócrifo, segundo o qual o Profeta teria condenado tais identidades.

\footnotetext{
102 Supra.

${ }^{103}$ No texto original: "[...] condenar qualquer serviço sexual que Hit prodigana* contra remuneración?" Para melhor compreensão do texto-sentido, algumas das definições (sinônimos) da palavra prodigaba: dissipar, gastar com excesso, desperdiçar, dar com abundância, promover entusiasticamente elogios, exceder-se de forma indiscreta e exibicionista a sua imagem pessoa. Como compreendido das informações encontradas em 'Significado de prodigaba - prodigar. Disponível em: https://www.nombra.me/significadoacentuacion-rimas/prodigaba.html. Acesso em: 01/06/2018.

${ }^{104}$ A paz e as bênçãos de Allah estejam com ele.

105 Abu Dawud, op. cit. ; Livro 42, capítulo 61, hadith 4930.

${ }^{106}$ Veja por exemplo, (Alcorão: 2,62, Alcorão: 3,64).
} 


\section{Conclusão}

Estez últimos também apontaram que não existe um consenso claro sobre a homossexualidade - ijma ${ }^{\prime 107}$ - por parte dos estudiosos eruditos do Islã. Hoje em dia, em todo o mundo, surgem novas representações da ética islâmica e emergem termos de gênero e sexualidade. O principal objetivo deste trabalho não foi detalhar $o$ posicionamento axiológico e político desses muçulmanos ou de um novo modelo, que em sua maioria fazem parte de minorias sexuais ou de gênero: mulheres, transexuais, transgêneros, homossexuais, e outros ${ }^{108}$. A presente produção intelectual, formulada nos termos de um retorno às fontes de conhecimento islâmico, sem dúvida, contribuirá indubitavelmente para culturas de diversidade democrática, secular, laica e libertadora, do coração da chamada civilização árabe-muçulmana.

Recebido em: 28-02-2019 Aceito em: 11-03-2019

\footnotetext{
${ }^{107}$ Ijma' - Ijmā’, (árabe: “consenso”) na lei islâmica, o acordo universal e infalível da comunidade muçulmana como um todo ou (de) estudiosos muçulmanos em particular. O consenso - às vezes justificado através de um ditado da Hadith (tradições dos ditos e ações do Profeta Mohamad [...] constitui uma das fontes da jurisprudência islâmica, usūl al-fiqh (raízes da lei). O corpo de princípios e metodologias investigativas através do qual regras legais práticas são desenvolvidas a partir das fontes fundamentais. A base primária da lei é o Alcorão. A segunda fonte é a Sunnah, relatórios sobre os ditos, ações ou aprovações tácitas do Profeta. A terceira fonte é o consenso (ijma) de todos os estudiosos muçulmanos interpretativos em uma idade específica sobre uma regra legal sobre uma questão não coberta no Alcorão ou Sunnah. A maioria dos estudiosos sunitas considera o consenso vinculativo; outros, incluindo estudiosos xiitas, dizem que tal consenso é impossível. A quarta fonte é analogia (qiyas) ou regra por precedente. Alguns Hanafis, como Ibn Abidin e Maliki juristas, consideram o urf (costume) como uma fonte adicional de lei. Além dessas fontes básicas, várias presunções e princípios auxiliam o jurista a derivar regras interpretativas: preferência (istihsan), interesse não regulado (maslahah mursalah) e a presunção de continuidade (istishab). Este campo também está preocupado com os princípios hermenêuticos e dedutivos. Fonte: $\mathrm{O}$ Dicionário Oxford do Islã. Disponível em: http://www.oxfordislamicstudies.com/article/opr/t125/e2444. Acesso em: 01/06/2018.

${ }^{108}$ Para saber mais sobre este tema: Zahed, L. (2017). "Islams em Devenirs: l'emergence d'éthiques islamiques libératruices, réformées, para a consciência acumular des genres \& des corpoités" - "Tornarse Islã: o surgimento da ética islâmica libertadora e reformada, para uma acumulação de talentos e corpos". CALEM, Marselha (www.calem.eu). Acesso em: 01/06/2018.
} 